\title{
LAW AND MEDICINE: THE INFLUENCE OF FUNDAMENTAL RIGHTS ON THE CORONA- CRISIS AND THE INFLUENCE OF THE CORONA-CRISIS ON FUNDAMENTAL RIGHTS IN THE EU
}

Accepted
12. 08. 2021
Revised
20. 09. 2021
Published
29. 10. 2021

Keywords

fundamental

rights,

Corona

crisis,

restrictions,

law and

medicine,

constitutional

court

\author{
Verica Trstenjak \\ Univerza v Ljubljani, Pravna fakulteta, Ljubljana, Slovenia. \\ Sigmund Freud University Vienna, Vienna, Austria. \\ E-mail: trstenjakverica@gmail.com \\ CORRESPONDING AUTHOR \\ trstenjakverica@gmail.com
}




\section{$1 \quad$ Introduction}

Law and medicine are two mutually interconnected areas. Unquestionably, we need medicine and physicians. The Corona-crisis has heightened awareness of the need for law to support medicine so as to enable it to deliver the most superior results possible. Law has imposed restrictions, typically informed by proposals made by experts, during the Corona-crisis. Legal acts were adopted, for example, on the basis of proposals made by doctors relying on the number of infected people, people treated in hospitals, the danger of the virus and the like. Expert opinions were also provided by other professionals such as statisticians, who study and calculate the spread of virus. ${ }^{1}$

The article will critically analyse the field of fundamental rights in the EU and explain the circumstances when these rights can be restricted. It also will examine legal acts at the EU level as well as case law of the Court of Justice of the EU, which have a significant impact in this area. Considering the Corona-crisis, the rights relevant to this specific period in 2020 and 2021 will be assessed, as well as the responses of national courts in EU Member States. We will specifically analyse the possibilities of restricting fundamental rights due to health related-issues in this unique context.

The introductory part of this article shall highlight the terminological and historic difference between human rights and fundamental rights. Some legal scholars consider that an important difference between the two terms lies in the fact that fundamental rights comprise both human and civil rights. However, in essence, they also comprise so-called social rights. The understanding of both terms will be facilitated by the finding that the EU, comprised of 27 Member States, applies the term fundamental rights, while the Council of Europe, with 47 contracting states, applies the term human rights, which is also governed by the European Convention on Human Rights (Convention for the Protection of Human Rights and Fundamental Freedoms). The term human rights is also used by some other international acts such as the UN Universal Declaration of Human Rights adopted in 1948 at the global level.

\footnotetext{
${ }^{1}$ In Slovenia, for example, experts from the Institute Josef Stefan, available at: https://www.ijs.si/ijsw/Korona (accessed on 21 June 2021).
} 


\section{Fundamental Rights in the EU}

\subsection{The Charter}

At the EU level, fundamental rights are governed by the Charter of Fundamental Rights of the European Union (hereinafter : the Charter). ${ }^{2}$ The Charter was adopted in 2000, but it has been legally binding since 2009 and forms part of the primary law under Article 6 of the Treaty on European Union. ${ }^{3}$ Though not called the constitution, it nonetheless is the preeminent legal act of the EU in the field of fundamental rights. Its content, its validity as well as its legal value can nevertheless be favourably compared to a constitution. The Court of Justice of the EU (hereinafter: CJEU) in Luxembourg has recognized the constitutional importance of the Charter. ${ }^{4}$ In fact, we can quite reasonably draw a favourable comparison of the Charter to the Magna Carta or perhaps even the European Bible as far as our rights in the EU are concerned. The Charter catalogues various specific rights, freedoms and principles. However, the generic term "fundamental rights" is applied when individual articles of the Charter are considered and discussed.

The Charter is a short legal Act, consisting of only 54 articles. However, its individual provisions are of extreme importance as the Charter concisely encapsulates classic human rights (right to life in Article 2), as well as certain other rights not belonging in the category of classic human rights, for example, in the field of worker's rights (for example, Article 31), a consumer protection (Article 38) and, as particularly relates to the subject of this paper, an extremely important provision on health care Article 35).

Significantly, most of the rights governed by the Charter are of general application and apply to all individuals, not only to citizens of the EU (such as human dignity, prohibition of torture, etc.). Rights stipulated in Chapter V of the Charter apply in principle only to citizens of the $\mathrm{EU}$ (such as the right to vote in elections to the European Parliament) or to individuals residing or having its registered office in a

\footnotetext{
${ }^{2}$ Charter of Fundamental Rights of the European Union, OJ EU C 326, 26. 10. 2012.

${ }^{3}$ Article 6(1) of the TEU reads as follows: "1. The Union recognises the rights, freedoms and principles set out in the Charter of Fundamental Rights of the European Union of 7 December 2000, as adapted at Strasbourg, on 12 December 2007, which shall have the same legal value as the Treaties".

${ }^{4}$ Opinion of the Court 1/17 [CETA], EU:C:2019:341, para. 110.
} 
Member State of the EU (for example, right of access to documents of the institutions, bodies, offices and agencies of the EU).

\subsection{Restrictions and Limitations of Fundamental Rights}

The rights enshrined in the Charter (mutatis mutandis the same conclusion is to be applied to constitutions of Member States) are conferred on individuals, but are not absolute. Restrictions and limitations governed by the Charter are frequently subjected to judicial interpretation in the case-law of the CJEU.

Article 52(1) of the Charter contains provisions on limitations of fundamental rights. Any limitation on the exercise of the rights and freedoms is permissible only if certain conditions are met; the limitations must be provided for by law and respect the essence of those rights and freedoms. Subject to the principle of proportionality, limitations may be made only if they are necessary and genuinely meet objectives of general interest recognised by the Union or the need to protect the rights and freedoms of others.

The provision on limitations that must be "provided for by law" refers to legal acts of the EU as well as legal acts of Member States. As the Charter contains the term "law" (in Slovenian: zakon), the said term and its scope have to be interpreted according to the meaning ascribed to in each Member State or in EU law. Importantly, the EU does not adopt laws as legal acts. Moreover, not all Member States consider the law as the sole second highest legal act following the constitution. The CJEU ruled that the requirement that any limitation on the exercise of that right must be provided for by law implies that the legal basis must not only itself define the scope of the limitation on the exercise of the right but it must also afford a measure of legal protection against any arbitrary interferences. ${ }^{5}$ For example, we can observe special legal acts on proceedings and actions during the spread of contagious and infectious diseases. ${ }^{6}$ During the Corona-crisis almost all States adopted special laws and other legal acts - not called laws. Moreover, governments of States wanted a legislative endorsement in parliaments ${ }^{7}$ or adopted special legal acts with the force of law that can be adopted in extraordinary circumstances (state of emergency). The

\footnotetext{
${ }^{5}$ See in this sense Case C-419/14 WebMindLicenses EU:C:2015:832, para 81.

${ }^{6}$ See in Austria the Law on Epidemics (Epidemiegesetz), Federal Official Journal of Austria, Nr. 186/1950 as amended.

${ }^{7}$ Cf. the laws cited above in note 1.
} 
pandemics were a reason for the adoption of "special" laws due to infectious diseases. ${ }^{8}$ A majority of States allow for the adoption of special measures based on the rulings declaring the pandemics. National procedural specificities for adoption of such acts vary from one State to another.

The conditions stipulated in Article 52(1) of the Charter that "the essence of rights and freedoms" are to be respected are assessed on a case-by-case basis. The CJEU clarified the essence of the rights under Articles 7 and 8 of the Charter in the Opinion 1/15 on the draft agreement between Canada and the EU on the transfer and processing of passenger name record data. Regarding the essence of Article 7 of the Charter (respect for private life), the CJEU held that even if PNR data (database of names of all air passengers) may, in some circumstances, reveal very specific information concerning the private life of a person, the nature of that information is limited to certain aspects of that private life, in particular, relating to air travel between Canada and the EU. Regarding the essence of the right under Article 8 of the Charter (protection of personal data), the CJEU held that the envisaged agreement limits, in Article 3, the purposes for which PNR data may be processed, and lays down, in Article 9, rules intended to ensure, inter alia, the security, confidentiality and integrity of that data, and to protect it against unlawful access and processing. ${ }^{9}$ Hence, the CJEU held that "the interferences which the envisaged agreement entails are capable of being justified by an objective of general interest of the European Union and are not liable adversely to affect the essence of the fundamental rights enshrined in Articles 7 and 8 of the Charter". ${ }^{10}$

When examining Article 52(1) of the Charter, the CJEU also assesses "objectives of general interest". I already mentioned the assessment undertaken by the Court in the Opinion 1/15 on the agreement with Canada in so far as Article 7 and 8 of the Charter are concerned. ${ }^{11}$

\footnotetext{
${ }^{8}$ See, for example, for example, on the basis of Article 7 of the Slovenian Communicable Diseases Act (Zakon o nalezljivih boleznib), OJ RS No. 65/95, and the Minister of Health's Decree on declaration of contagious disease SARS-Cov-2 (COVID-19) (Odredba o razglasitvi epidemije nalezljive bolezni SARS-CoV-2 (COVID-19) na obmoğju Republike Slovenije), OJ RS, No. 19/20.

${ }^{9}$ Opinion $1 / 15$ on the draft agreement between Canada and the European Union on Transfer of Passenger Name Record data from the European Union to Canada, EU:C:2017:592, para. 150.

${ }^{10}$ Cf. ibid, para. 151.

${ }^{11}$ Cf. ibid.
} 
The proportionality as a condition for limitations of fundamental rights under Article 52(1) of the Charter is an extremely important criterion of assessment. The CJEU confirmed that, according to the settled case-law, the principle of proportionality requires that measures adopted by EU institutions or Member States "do not exceed the limits of what is appropriate and necessary in order to attain the objectives legitimately pursued by the legislation in question; when there is a choice between several appropriate measures recourse must be had to the least onerous, and the disadvantages caused must not be disproportionate to the aims pursued." 12

The CJEU assesses, in principle, two elements of proportionality: the appropriateness (in German: die Geeignetheit) and necessity (in German: die Erforderlichkeit) of the adopted measures. The opinions of Advocates General are sometimes even "broader", as they apply the standard of three steps of proportionality (Trstenjak \& Beysen, 2013: 314; Trstenjak \& Beysen, 2012: 282-283). The test of proportionality as a consequence comprises the appropriateness, necessity and the reasonableness ${ }^{13}$ of excessive interference, which can also be translated as the answer to the question whether the measures are reasonable (in German: die Angemessenheit). ${ }^{14}$

\footnotetext{
12 Cf. Case C-283/11 Sky Österreich EU:C:2013:28, para 50; see also Case C-343/09 Afton Chemical EU:C:2010:419, para. 45; Joined Cases C-581/10 and C-629/10 Nelson and Others EU:C:2012:657, para. 71. Regarding Member States, see: Case C-2/10 Arienda Agro-Zootecnica Franchini in Eolica di Altamura EU:C:2011:502, para. 73; Case C-28/05 Dokter and Others EU:C:2006:408, para. 72; C-434/02 Arnold André EU:C:2004:800, para. 45.

${ }^{13}$ Slovenian language applies the term "sorazmernost v ožjem pomenu", the English language applies the term "reasonableness", the German language applies the term "Angemessenheit", and the French language applies the term "le caractère mesuré". Cf. the relevant linguistic versions of the opinion of Advocate General Trstenjak in Case C-28/09 Commission v Austria EU:C:2010:770, para. 118.

${ }^{14}$ Cf. Opinion of Advocate General Cruz Villalon in Case C-580/13 Stadtsparkasse Magdeburg EU:C:2015:243, para. 43. See also opinion of Advocate General Trstenjak in the Case C-28/09 Commission v Austria EU:C:2010:770 on sectoral traffic prohibition for lorries of more than 7.5 tonnes carrying certain goods in Austria (Tirol), where the question was rather the limitation of fundamental economic freedoms. Cf. paras 93 and 118-132. Para. 118 reads as follows: "If, contrary to the view taken here, the Court concluded that the regulation on the sectoral traffic probibition passes the necessity test, it would be necessary to examine, in addition, whether this probibition restricted the free movement of goods in an unreasonable manner. This would be the case if, in spite of its favourable environmental effects, the sectoral traffic probibition resulted in excessive interference with the free movement of goods".
} 


\subsection{Case law of the Court of Justice of the EU Concerning Protection of Health}

The CJEU has already ruled in numerous cases on protection of health. In the case C-547/14, Philip Morris, for example, the CJEU interpreted the provisions on health care contained in the Charter. The referring British court asked the CJEU, inter alia, whether Article 13(1) of Directive 2014/40, pertaining to tobacco products, ${ }^{15}$ must be interpreted as prohibiting the display of certain information (even though factual accurate) not only on the labelling of unit packets, but also on the outside packaging, as well as on the tobacco product itself, and, if that is the case, whether that provision was invalid because it infringes Article 11 of the Charter and the principle of proportionality. The CJEU gave a statement of reasons referring to Article 35 of the Charter (health care) when assessing the proportionality of the interference. It underlined that the second sentence of Article 35 of the Charter, when considered in conjunction with Article 9 of the Treaty on the Functioning of the EU (hereinafter: TFEU), 114(3) TFEU and 168(1) TFEU require that a high level of human health protection be ensured in the definition and implementation of all the Union's policies and activities. The CJEU acknowledged that the prohibition on the inclusion of the labelling of unit packets and on outside packaging, as well as on the tobacco product itself, constitutes an interference with a business's freedom of expression and information. However, in accordance with Article 52(1) of the Charter, any limitation on the exercise of the rights and freedoms laid down by the Charter must be provided for by law and respect the essence of those rights and freedoms; must comply with the principle of proportionality; and, must actually meet objectives of general interest recognised by the EU or the need to protect the rights and freedoms of others. ${ }^{16}$

Further, the CJEU referred also to Article 35 of the Charter (health care) and emphasized the importance of striking a fair balance in the exercise of rights. The CJEU held that "the discretion enjoyed by the EU legislature, in determining the balance to be struck, varies for each of the goals justifying restrictions on that freedom and depends on the nature of the activities in question. In the present case,

\footnotetext{
${ }^{15}$ Directive 2014/40/EU of the European Parliament and of the Council of 3 April 2014 on the approximation of the laws, regulations and administrative provisions of the Member States concerning the manufacture, presentation and sale of tobacco and related products and repealing Directive 2001/37/EC, OJ L 127, 29.4.2014.

${ }^{16}$ Cf. C-547/14 Philip Morris Brands and Others EU:C:2016:325, paras 148-150.
} 
the claimants in the main proceedings rely, in essence, under Article 11 of the Charter, on the freedom to disseminate information in pursuit of their commercial interests. It must, however, be stated that human health protection - in an area characterised by the proven harmfulness of tobacco consumption, by the addictive effects of tobacco and by the incidence of serious diseases caused by the compounds those products contain that are pharmacologically active, toxic, mutagenic and carcinogenic - outweighs the interests put forward by the claimants in the main proceedings". ${ }^{17}$

Relying upon Article 35 of the Charter (health care), the CJEU found that the conditions set for limitations were met and the cited contentious provisions of the Directive 2014/40 shall remain valid as they do not infringe upon the provisions of the Charter. Futhermore, the conditions are justified in accordance with Article 52(1) of the Charter and other provisions of primary law as the just equilibrium between requirements of freedom of expression and information on the one hand and the requirements of public health of individuals on the other hand were met.

\section{Key Charter's Fundamental Rights During the Corona Crisis}

\subsection{Introductory Remarks}

In the period of the Corona-crisis, the key issues have been linked to the questions regarding when and under what conditions fundamental rights could be limited and what is a fair balance between competing fundamental rights in a case where several fundamental rights are in conflict.

In practice, (public) health has almost always been applied as a limitation to all fundamental rights. Examples of such limitations are the restriction of freedom of movement against protection of health, interferences with privacy or protection of personal data due to health, the restriction of freedom to conduct a business (for example, compulsory closures of shops) versus protection of health, and equality before the law against public health protection, etc.

${ }^{17}$ Cf. ibid, paras 155 and 156. 
The application of the conditions governed by Article 52(1) of the Charter is important in cases involving the "collision" of several fundamental rights. When such cases occur, both the competent authorities and courts are called upon to decide on just equilibrium between competing fundamental rights as often recalled in the case-law of the CJEU.

\subsection{Health Care (Article 35 of the Charter), Right to Life (Article 2 of the Charter)}

The first key provision is Article 35 of the Charter dealing with health care. Article 35 provides that everyone has not only the right of access to preventive health care but also the right to benefit from medical treatment under the conditions established by national laws and practices. This text is extremely important as there are significant differences between Member States with respect to laws providing measures to tackle the Corona-crisis. Moreover, the second sentence of Article 35 provides that "A high level of human health protection shall be ensured in the definition and implementation of all the Union's policies and activities."

Human health protection is also referred to in other provisions of primary law of the EU, for example Article 168 TFEU.

However, Article 35 of the Charter does not directly confer rights on individuals, as this provision is to be realized both at the EU level and by national laws and customs. This right was most frequently referred to during the Corona-crisis as a justification when limitations were imposed on other fundamental rights.

Apart from the right to health care (Article 35 of the Charter), the right to life, as embodied in Article 2, was most frequently cited as a limitation on other fundamental rights. In order to protect these two rights (sometimes the right to human dignity from Article 1 of the Charter is also mentioned), other fundamental rights had to be restricted. However, as mentioned, these rights can be restricted only if the previously identified conditions from Article 52(1) of the Charter are fulfilled. 


\subsection{Fundamental Rights that Have to Be Restricted in order to Protect Health and the Right to Life}

Many rights were restricted during the Corona-crisis. Some of the most commonly restricted fundamental rights (or at least referred to in practice) will be mentioned below. Article 6 of the Charter, governing the right to liberty and security, was often cited by courts and competent authorities during the Corona-crisis. Both those who wanted more expansive freedom of movement (the right to liberty) as well as those who insisted on human health protection - as enshrined in the second part of the provision - (Security) referred to this Article.

Article 6 regulates a right to physical free movement, which protects also against illicit interferences or limitations of that right. The text refers to two elements, i.e. the liberty and the security. Legal scholars assert that these provisions are to be interpreted as a whole. ${ }^{18}$

The right to protection of personal data was often discussed during the Coronacrisis. This topic is extremely relevant due to the processing of data of diseased persons and/or due to the proposed possible ways and means of tracing not only the infected person but that person's contacts as well. The said right refers to the protection of personal data concerning data subjects (individuals). According to Article 8(2) of the Charter, personal data "must be processed fairly for specified purposes and on the basis of the consent of the person concerned or some other legitimate basis laid down by law [and] [E]veryone has the right of access to data which has been collected concerning him or her, and the right to have it rectified. Compliance with [Article 8] shall be subject to control by an independent authority."

This right is not absolute, but must be balanced not only in accordance with the principle of proportionality in relation to its function in society, but also with other fundamental rights. ${ }^{19}$

\footnotetext{
${ }^{18}$ See in detail in Schramm, in (Holoubek \& Lienbacher, 2014: 73).

${ }^{19}$ See in this sense the Joined Cases C-92/09 and C-93/09 Volker und Markus Schecke and Eifert EU:C:2010:662, para. 48.
} 
The right to protection of personal data is increasingly important in society, especially after the entry into force of Regulation (EU) 2016/679 of the European Parliament and of the Council of 27 April 2016 on the protection of natural persons with regard to the processing of personal data and on the free movement of such data, and the repeal of Directive 95/46/EC (General Data Protection Regulation, GDPR). ${ }^{20}$

Recital 46 of the Preamble to the GDPR provides that the processing of personal data should be regarded as lawful where it is necessary to protect an interest which is essential for the life of the data subject or that of another natural person. This recital provides further that "processing of personal data based on the vital interest of another natural person should in principle take place only where the processing cannot be manifestly based on another legal basis. Some types of processing may serve both important grounds of public interest and the vital interests of the data subject as for instance when processing is necessary for humanitarian purposes, including for monitoring epidemics and their spread or in situations of humanitarian emergencies, in particular in situations of natural and man-made disasters."

Articles 6 and 9 of the GDPR contain several exceptions. The exception to the prohibition of data processing in Article 9(2)(i) applies where data "processing is necessary for reasons of public interest in the area of public health, such as protecting against serious cross-border threats to health or ensuring high standards of quality and safety of health care and of medicinal products or medical devices, on the basis of Union or Member State law which provides for suitable and specific measures to safeguard the rights and freedoms of the data subject, in particular professional secrecy."

The Corona-crisis exposed numerous problems related to various types of data gatherings, controls and data processing relating to the disease, several technological methods in the information society for tracing of the infected, as well as of those in their vicinity etc. Legal experts expressed differing views during several webinars during the Corona-crisis. Among them was a well-known data protection activist

\footnotetext{
${ }^{20}$ Regulation (EU) 2016/679 of the European Parliament and of the Council of 27 April 2016 on the protection of natural persons with regard to the processing of personal data and on the free movement of such data, and repealing Directive 95/46/EC (General Data Protection Regulation), OJ L 119, 4.5.2016.
} 
Maximilian Schrems. ${ }^{21}$ The use of tracing applications will probably have to be based on consent in the light of a high level of legal protection bestowed upon personal data. The novel legal problem associated with tracing applications and similar systems will be the qualification of these applications as a "medical device," which would then allow them broader interference with protected other rights. It would also be useful to consider the development of a uniform European application, ${ }^{22}$ which would allow an equal level of protection of personal data across the EU.

The rights to freedom of peaceful assembly and to freedom of association (Article 12 of the Charter) apply at all levels, in particular in political, trade union and civic matters, which implies the right of everyone to form and to join trade unions for the protection of his or her interests.

The right to equality before the law (Article 20 of the Charter) provides that everyone is equal before the law and is also important during the Corona-crisis.

One of the most important rights of modern society is the right to respect for private and family life (Article 7 of the Charter), or so called right to privacy, which includes the right to respect for one's private and family life, housing and communications. At the time of the Corona-crisis, this right was invoked in relation to employers' requirements for measurement of body temperature and also for wearing masks, as well as the issue of visits by family members due to measures against the COVID.

The prohibition of discrimination (non-discrimination), which is extensively defined in Article 21(1) of the Charter, has been invoked in various circumstances: regarding the restriction of the elderly to enter into shops, with regard to young people and the prohibition of visiting grandparents, etc.

The interference with the right to judicial remedy, i.e. the right to an effective remedy and to a fair trial under Article 47 of the Charter, was also addressed during the Corona-crisis. As the courts were in recess and no hearings were set, the length of procedures was extended. Certain Member States solved the problem of deadlines

\footnotetext{
${ }^{21}$ Maximilian Schrems, 'Datenschutz in Zeiten des Coronavirus' (2020), available at: https://noyb.eu/de/datenschutz-zeiten-von-corona (accessed 16 May 2020).

${ }^{22}$ The Luxembourg's proposal in the Council of Ministers on 5 May 2020.
} 
and statutes of limitations by enacting special laws. ${ }^{23}$ Individuals in proceedings had recourse to the said right in cases where they had to appear before a court (as there could be a risk for their health) ${ }^{24}$ as well as in cases where no hearings were scheduled. ${ }^{25}$ However, spokespeople for the industry and commerce sectors especially warned of the lack of protection of creditors and other problems due to interruption of proceedings (Bruckmüller, 2020).

During the Corona crisis, special attention was paid to freedom of expression and information, both in relation to individuals and in the media, as defined in Article 11 of the Charter.

Article 38 of the Charter on consumer protection shall also be mentioned. Due to the crisis, many problems have arisen in the area of consumer protection, especially with regard to non-refund of money for pre-paid trips and flights and offering vouchers or coupons. These problems become particularly acute if the companies go bankrupt. ${ }^{26}$ Consumer organizations also warned of the possibility of withdrawal from distance contracts, of unfair business practices, advertisements for "medina" masks, advertisements for bogus "medicines" for the virus, excessive price increases for certain products (for example, masks, disinfectants).

\section{The Assessment of Restrictions of Fundamental Rights During the Corona-crisis}

\subsection{EU level}

Given the course of proceedings at the EU level, we can expect numerous proceedings at the EU level before the CJEU in the coming years. Proceedings before the CJEU are usually a "continuation" of proceedings litigated at a national level. Such proceedings are preliminary ruling proceedings under Article 267 TFEU, where a national judge asks the CJEU to give a ruling on the interpretation of EU

\footnotetext{
${ }^{23}$ In Slovenia, for example, Act on provisional measures for judicial, administrative and other public matters to cope with the spread of infectious disease SARS-CoV-2 (COVID-19), OJ RS No. 36/20 and 61/20.

${ }^{24} \mathrm{See}$, for example, in Germany a case before the Federal Constitutional Court (Bundesverfassungsgericht) $2 \mathrm{BvR}$ $483 / 20$.

${ }^{25}$ See, for example, in Germany a case before the Federal Constitutional Court (Bundesverfassungsgericht) 2 BvR $474 / 20$.

${ }^{26}$ The coupons are mentioned by the Slovenian Law on Measures of Intervention to Contain the COVID-19 Epidemics and Mitigate its Consequences for Citizens and the Economy (see supra Fn. 1), see Article 101a.
} 
law. In addition to such judicial proceedings, there are several other proceedings already pending at the EU level, such as actions for annulment of state aid in times of crisis. ${ }^{27}$ However, these proceedings are not related to fundamental rights.

As far as available legal remedies in the EU are concerned, the European Commission could also initiate infringement proceedings against Member States for non-compliance or breach of EU law under Articles 258 and 260(2) TFEU, which allow for sanctions to be imposed on any Member State that fails to comply with a judgment of the CJEU. In 2020-2021, such a proceeding regarding the Corona-crisis has yet to be initiated. However, an action was filed by the European Commission in connection with the allegedly inadequate supply of the AstraZeneca vaccine, as the other contractual party (i.e. AstraZeneca) allegedly did not comply with agreed deadlines. This is not an action under EU law, however, but rather under Belgian law and under the jurisdiction of Belgian courts, as the European Commission is based in Brussels. The case is one for specific performance of a contractual obligation, where both the jurisdiction and the choice of law are vested at the state level in accordance with Article 340(1) TFEU. The court of first instance of Brussels decided on 18 June 2021 to grant an interim measure in the case brought against AstraZeneca by the European Commission and the 27 EU Member States. The competent Belgian court ruled that AstraZeneca is required to deliver yet another 50 million doses of vaccine by the end of September 2021.28

\subsection{Member States level}

There are several possibilities for initiating legal and judicial proceedings in Member States. Such proceedings may be either of a civil nature, for example, claims for compensation, or a criminal nature. A notable case involves the Austrian town of Ischgl in Tirol, where several thousands of people, later scattered across the EU, were infected while skiing in Ischgl. Several proceedings and remedies are possible. An Austrian lawyer, Dr. Kolba, who manages the (Austrian) Consumer Protection Association (Verbraucherschutzverein VSV), is gathering victims for a class action for compensation against the Land of Tirol and others that may have liablity. ${ }^{29} \mathrm{By}$

\footnotetext{
${ }^{27}$ See for example, Ryanair v European Commission, T-259/20.

28 See, for example https://ec.europa.eu/commission/presscorner/detail/en/IP_21_3090, accessed on 21 June 2021

${ }^{29}$ See, for example, Nadine Schmidt, 'Authorities in Tyrol are accused of having reacted too late to the first signs of the coronavirus outbreak in Tyrol -- particularly in Ischgl - contributing to the spread of the virus in Europe and
} 
the end of April 2020, thousands of people had joined that class action. ${ }^{30}$ Many European and world media wrote extensively on the matter. ${ }^{31}$ The media also mentioned possible criminal charges against those responsible, both the managers of tourist/catering establishments and holders of political powers in Ischgl and in Tirol. ${ }^{32}$ Besides civil and criminal responsibility, the possibility of political responsibility should not be overlooked. Thus, in Ischgl, a question regarding a motion of no-confidence against a provincial politician has already been raised. ${ }^{33}$

In many countries, constitutional courts at the national level have already adjudicated the legality of governmentally imposed restrictions placed on fundamental rights during the Corona-crisis, on the basis of national constitutions. We will briefly examine some examples arising from Austria, Germany and Slovenia. In several Member States, many requests for constitutional review have been rejected (or even declared inadmissible), while some have been granted.

Often, however, constitutional courts constrained the scope of their rulings, holding only that there was an unconstitutional interference with human rights on the sole grounds that the competent authorities had acted illegally by applying the erroneous legal instruments, while not reaching the issue whether the specific restrictions were unconstitutional per se (i.e. because of the content of such restrictions). To put it simply for non-lawyers, these courts ruled only that the procedure(s) for adoption of the legal acts was unconstitutional, not (necessarily) the content or aim. Thus, in such cases these constitutional courts did not assess the proportionality of

beyond' (2020), See, for example, in Germany a case before the Federal Constitutional Court (Bundesverfassungsgericht) 2 BvR 483/20. https://edition.cnn.com/travel /article/austria-ski-resort-ischglcoronavirus-intl/index.html, (accessed 16 May 2020).

30 The majority of persons having joined the class action come from Germany (roughly 70 percent according to available data), less from Austria and also two persons from Slovenia and two from the US, see https://www.verbraucherschutzverein.at/Corona-Virus-Tirol/, accessed 16 May 2020.

31 See in Germany, for example, Watson, 'Corona-Schleuder" Ischgl: Österreich droht teure Sammelklage' (2020) https://www.watson.de/international/coronavirus/575437490-corona-schleuder-ischgl-oesterreich-droht-teuresammelklage, accessed 16 May 2020; Nadine Schmidt, 'Austrian officials face lawsuit from 2,500 tourists over ski resort outbreak' (2020) https://edition.cnn.com/travel/article/austria-ski-resort-ischgl-coronavirusintl/index.html, accessed 16 May 2020; Derek Scally, 'Class-action lawsuit launched over Covid-19 ski resort' (2020) https://www.irishtimes.com/news/world/europe/class-action-lawsuit-launched-over-covid-19-ski-resort-

1.4235393 , accessed 16 May 2020.

32 See, for example, Nadine Schmidt, 'The public prosecutor will have to examine whether something went wrong and if so, what exactly went wrong' (2020) https://edition.cnn.com/travel/article/austria-ski-resort-ischglcoronavirus-intl/index.html, accessed 16 May 2020.

33 See Die Presse, 'Causa Ischgl: Opposition stellt Misstrauensantrag gegen Landesrat Tilg' (2020), available at: https://www.diepresse.com/5812108/causa-ischgl-opposition-stellt-misstrauensantrag-gegen-landesrat-tilg, (accessed 16 May 2020). 
restrictions, as these courts concluded there was an infringement of an essential procedural requirement(s) in adoption of the measures dealing with restrictions. Most of the time, these courts noted that the specific deficiency in the legal instruments was that restrictions on fundamental rights were not contained in the laws and acts passed by national parliaments (as required by both the EU Charter and several national constitutions), but rather in regulatory instruments such as government decrees and instruments adopted to enforce acts of parliament. This is the essence of the decision of the Slovenian Constitutional Court (Ustavno sodišče RS) of 20 May 2021 in case U-I-79/20.

In this case, the Constitutional Court of Slovenia, upon request of several petitioners, reviewed subparagraphs 2 and 3 of Article 39(1) of the Infectious Diseases Act, ${ }^{34}$ which authorizes the Government to restrict the movement and public gatherings of the population in order to prevent the entry of a contagious disease in the country or its spread. It also assessed several Government decrees adopted on the basis of the above-mentioned legal provisions from April to October 2020, in order to contain and control the spread of the COVID-19 epidemics. The Constitutional Court ruled that the above-mentioned provisions of the Infectious Diseases Act do not comply with the Constitution and ordered the legislator to adopt the relevant provisions within two months. Consequently, based on the argument a maiori ad minus, the challenged decrees adopted by the Government on the basis of the above-mentioned unconstitutional law is also unconstitutional. However, it should be stressed the law is a general and abstract legal norm and that it will not be possible to enumerate all concrete elements of a concrete restriction (for example, that the law prescribes the mandatory wearing of masks) in the texts of the law. The ruling has been both applauded and rebuked by commentators and experts. ${ }^{35}$

On several occasions, the Austrian Constitutional Court (Verfassungsgerichtshof) also ruled on the constitutionality of various measures the Austrian Government took to try to control the spread of the virus. In 2020, the Court decided that the Austrian law on COVID-related measures was constitutional, but also that some ordinances

\footnotetext{
${ }^{34}$ Communicable Diseases Act (Zakon o nalezljivih boleznih), OJ RS No. 65/95

35 See a critical assessment by Matej Avbelj 'Pra-odločba ustavnega sodišča', available at: https://iusinfo.si/medijsko-sredisce/kolumne/284313, (accessed 25 June 2021). For a positive view, see for example an opinion of Saša Zagorc presented on the website Ius-Info, available at: https://www.iusinfo.si/medijskosredisce/dnevne-novice/284179, (accessed 1 August 2021).
} 
and decrees were either unconstitutional or illegal. For example, the Court ruled on the one hand that although distance learning was legal, ${ }^{36}$ the restriction on access to sports facilities on the other hand was illegal because it was not sufficiently reasoned. ${ }^{37}$ In Germany, the German Federal Constitutional Court [hereinafter FCC] (Bundesverfassunggericht) has already examined many issues surrounding the constitutionality of various government-imposed COVID measures, including the closure of churches, and related issues impacting upon the freedom of religion, closure of gyms, closure of courts or hearings, prohibition of gatherings, compulsory use of face masks, the prohibition of outdoor activities and other restrictions of movement, etc ${ }^{38}$. Germany is, of course, a federation. The lockdown measures have been promulgated as regulatory instruments by the governments of the German Länder. Therefore, as a consequence, the highest courts in the Länder were often asked to issue rulings on these subjects. Nevertheless, the FCC also often issued rulings. Several problems arose in such litigation. First, there were doubts, similar to those raised in Slovenia, about the legislation on epidemics, particularly regarding whether the relevant provisions of the Act on infectious diseases (Infektionsschutssgesets) constitute a legitimate legal basis for the regulatory instruments, including the compliance of the said law with Article 80 of the Grundgesetz, (German Constitution). Article 80 imposes requirements on laws conferring the authorisation to adopt regulatory instruments by the federal government, a federal minister, or governments of Länder. ${ }^{39}$ Legal scholarship, however, draws attention to another problem, namely that "there are significant concerns as to the compliance of the statutory instruments with a whole range of fundamental rights from freedom of faith to freedom of assembly." 40 The FCC has indicated that the right to assembly, in some cases, and under certain conditions, may also be admissible in the time of the Corona pandemics. For example, the FCC

\footnotetext{
${ }^{36}$ See decision V 574/2020.

${ }^{37}$ See website of the Austrian Constitutional Court, available at: https://www.vfgh.gv.at/medien/Covid_Entschaedigungen_Betretungsverbot.de.php, (accessed on 21 June 2021). 38 See website of the German Federal Constitutional Court, available at: https://www. Bundesverfassungsgericht.de/SiteGlobals/Forms/Suche/Servicesuche_Formular.html;jsessionid=2E4656451071 0D24ACF79DC5C0D728E8.2_cid361?nn=5399998\&resourceId=5402340\&input_=5399998\&pageLocale=de\&t emplateQueryString $=$ corona\&sortOrder $=$ score + desc\&language $==$ de\&submit. $x=0 \&$ submit. $y=0$, (accessed 16 May 2021).

${ }^{39}$ See Holger Hestermeyer, 'Coronavirus Lockdown-Measures before the German Constitutional Court' (2021), available at: https://constitutionnet.org/news/coronavirus-lockdown-measures-german-constitut ional-court, (accessed 21 June 2021).

${ }^{40}$ Ibid.
} 
decided that a city (or the competent authority) had to decide anew whether a protest could be held under certain conditions or whether it should be prohibited. ${ }^{41}$

\section{$5 \quad$ Conclusion}

The Corona-crisis has shown that the cooperation and interdependence of medicine and law are critically important. Legal acts are adopted on the basis of proposals from experts, in this case physicians and other experts (for example, experts on evaluation of the spreading of the epidemics). However, lawyers and, finally, the constitutional courts, have the ultimate task to ensure that the adoption of restrictions in legal acts, in casu restrictions of fundamental rights, are in compliance with the constitutions. They must assess both the legality of the procedures used to adopt the restrictions as well as the substantive criteria of the restrictions. The principle of proportionality is of key importance in evaluating the constitutionality of the restrictions mandated by the legislation and must be taken into account when examining all interferences with fundamental rights. Going forward, we reasonably can expect that at the EU level many proceedings dealing with restrictions of fundamental rights will be initiated, as fundamental rights at the EU level are regulated by the EU Charter.

\section{Endnote}

An article with a similar content was published in the book Corona and the Law, Intersentia 2021, and in the Slovenian legal journal Pravna praksa (especially the section on restriction of fundamental rights).

\section{Legislation, Acts, Regulations or Court Decisions}

Austrian Constitutional Court, (2020) COVID-19-Gesetz ist verfa ssun gskonform, Verordnungen über Betretungsverbote waren teilweise gesetzwidrig, URL:

https://www.vfgh.gv.at/medien/Covid_Entschaedigungen_Betretungsverbot.de.php, accessed 21 June 2021.

BVerfG, Beschluss der 1. Kammer des Ersten Senats vom 15. April 2020-1 BvR 828/20, Rn. 1-19,

URL: http://www.bverfg.de/e/rk20200415_1bvr082820.html (20 July 2021).

C 434/02 Arnold André EU:C:2004:800.

C-547/14 Philip Morris Brands and Others EU:C:2016:325.

Case 2 BvR 474/20.

Case 2 BvR 483/20.

Case C 2/10 Azienda Agro Zootecnica Franchini in Eolica di Altamura EU:C:2011:502.

Case C 343/09 Afton Chemical EU:C:2010:419.

\footnotetext{
${ }^{41}$ BVerfG, Beschluss der 1. Kammer des Ersten Senats vom 15. April 2020-1 BvR 828/20, Rn. 1-19.
} 
Case C 419/14 WebMindLicenses EU:C:2015:832.

Case C-28/05 Dokter and Others EU:C:2006:408.

Case C-28/09 Commission v Austria EU:C:2010:770.

Case C-283/11 Sky Österreich EU:C:2013:28.

Charter of Fundamental Rights of the European Union, OJ EU C 326, 26. 10. 2012.

Epidemiegesetz, Federal Official Journal of Austria, Nr. 186/1950.

Joined Cases C 581/10 and C 629/10 Nelson and Others EU:C:2012:657.

Joined Cases C 92/09 and C 93/09 Volker und Markus Schecke and Eifert EU:C:2010:662.

Odredba o razglasitvi epidemije nalezljive bolezni SARS-CoV-2 (COVID-19) na območju Republike Slovenije, OJ RS, No. 19/20.

Opinion 1/15 on the draft agreement between Canada and the European Union on Transfer of Passenger Name Record data from the European Union to Canada, EU:C:2017:592.

Opinion of Advocate General Cruz Villalon in Case C-580/13 Stadtsparkasse Magdeburg EU:C:2015:243.

Opinion of Advocate General Trstenjak in the Case C-28/09 Commission v Austria EU:C:2010:770.

Opinion of the Court 1/17 [CETA], EU:C:2019:341.

Regulation (EU) 2016/679 of the European Parliament and of the Council of 27 April 2016 on the protection of natural persons with regard to the processing of personal data and on the free movement of such data, and repealing Directive 95/46/EC (General Data Protection Regulation), OJ L 119, 4.5.2016.

T-259/20 Ryanair v European Commission.

Vpogled $\mathrm{v}$ znanje o koronavirusu za slovensko javnost, Institute Josef Stefan, URL: https://www.ijs.si/ijsw/Korona.

Zakon o nalezljivih boleznih, OJ RS No. 65/95 with ammendments

\section{References}

Avbelj, M. (2021) Pra-odločba ustavnega sodišča, IUS-INFO, 7. 6. 2021, retrieved from: https://iusinfo.si/medijsko-sredisce/kolumne/284313, (25 June 2021).

European Commission Press Release (2021) Belgian Court orders AstraZeneca to deliver vaccine doses to the EU, European Commission, 18. 6. 2021, retrieved from: https://ec.europa.eu /commission/presscorner/detail/en/IP_21_3090 (21 June 2021).

Hestermeyer, H. (2021) Coronavirus Lockdown-Measures before the German Constitutional Court, Constitution.net, 30. 4. 2020, retrieved from: https://constitutionnet.org/news/coronaviruslockdown-measures-german-constitutional-court (21 June 2021).

Holoubek, M. \& Lienbacher, G. (eds) (2014) GRC-Kommentar: Charta der Grundrecbte der Europäischen Union (Wien: MANZ Verlag).

Trstenjak, V. \& Beysen E. (2012) Das Prinzip der Verhaltnismäßigkeit in der Unionsrechtsordnung, Europarecht, 47(3), pp. 265-284.

Trstenjak, V. \& Beysen E. (2013) The Growing Overlap of Fundamental Freedoms and Fundamental Rights in the Case Law of the CJEU, European Law Review, 38(3), pp. 293-315.

Zagorc, S. (2021) Zaradi odločitve ustavnega sodišča izrečene kazni ne bodo padle, IUS-INFO, retrieved from: https://www.iusinfo.si/medijsko-sredisce/dnevne-novice/284179 (1 August 2021). 
